ББК 63.4

$$
\begin{gathered}
\text { Организация конференции и издание материалов проведены } \\
\text { при финансовой поддержке Российского фонда фундаментальных исследований, } \\
\text { проект № 19-09-20008 }
\end{gathered}
$$

Утверждено к печати Ученым советом ИИМК РАН

Редакционная коллегия тома II: А. В. Поляков, Е. С. Ткач (отв. редакторы), М. Т. Кашуба, Л. Б. Кирчо, Е. А. Черлёнок, В. Я. Стёганцева, А. И. Климушина

Рещензенты: д. и. н. Л. Б. Вишняцкий, д. и. н. А. А. Выборнов

Программный комитет конференции: академик РАН, д. и. н., проф. М. Б. Пиотровский (Государственный Эрмитаж, почетный председатель); д. и. н. В. А. Лапшин (ИИМК РАН, председатель); д. и. н. А. В. Головнёв (МАЭ РАН, сопредседатель); д. и. н. В. А. Дергачёв (Высшая антропологическая школа, Молдова, сопредседатель); д. и. н. И. Ф. Попова (ИВР РАН, сопредседатель); академик АН Республики Узбекистан, д. и. н., проф. Э. В. Ртвеладзе (сопредседатель); к. и. н. А. В. Поляков (ИИМК РАН, зам. председателя); к. и. н. В. А. Алёкшин (ИИМК РАН, зам. председателя); д. и. н. Ю. Е. Берёзкин (МАЭ РАН); Dr., Prof. Н. Бороффка

(Германский археологический институт, Германия); В. С. Бочкарёв (ИИМК РАН);

Dr. Э. Кайзер (Свободный университет Берлина, Германия); к. и. н. М. Т. Кашуба (ИИМК РАН); д. и. н. Л. Б. Кирчо (ИИМК РАН); к. и. н. А. В. Кияшко (Южный федеральный университет); к. и. н. П. Ф. Кузнецов (СГСПУ); к. и. н. Н. М. Малов (СНИГУ); к. и. н. В. П. Никоноров (ИИМК РАН); Ю. Ю. Пиотровский (Государственный Эрмитаж); д. и. н., проф. Д. Г. Савинов (Институт истории СПбГУ); к. и. н. В. Н. Седых (Институт истории СПбГУ); к. и. н. Н. Н. Скакун (ИИМК РАН); к. и. н. Н. Ф. Соловьёва (ИИМК РАН); к. и. н. А. И. Торгоев (Государственный Эрмитаж); к. и. н. Е. А. Черлёнок (Институт истории СПбГУ)

Организационный комитет конференции: к. и. н. А. В. Поляков (ИИМК РАН, председатель); к. и. н. В. А. Алёкшин (ИИМК РАН, зам. председателя); В. С. Бочкарёв (ИИМК РАН); к. и. н. М. Т. Кашуба (ИИМК РАН); д. и. н. Л. Б. Кирчо (ИИМК РАН);

А. И. Климушина (ИИМК РАН, отв. секретарь); к. и. н. В. П. Никоноров (ИИМК РАН); Ю. Ю. Пиотровский (Государственный Эрмитаж); В. Я. Стеганцева (ИИМК РАН); В. В. Терёхина (ИИМК РАН, МАЭ РАН, отв. секретарь); к. и. н. Е. С. Ткач (ИИМК РАН); И. Ж. Тутаева (Государственный Эрмитаж); к. и. н. Е. А. Черлёнок (Институт истории СПбГУ)

Древности Восточной Европы, Центральной Азии и Южной Сибири в контексте связей и взаимодействий в евразийском культурном пространстве (новые данные и концепции): Материалы Международной конференции, 18-22 ноября 2019 г., Санкт-Петербург. Т. ІІ. Связи, контакты и взаимодействия древних культур Северной Евразии и цивилизаций Востока в эпоху палеометалла (IV-I тыс. до н. э.). К 80-летию со дня рождения выдающегося археолога В. С. Бочкарёва. - СПб.: ИИМК РАН, Невская Типография, 2019. - 287 с.

ISBN 978-5-907053-35-9

DOI 10.31600/978-5-907053-35-9 


\title{
Литература
}

Гусев С. А. 1998. К вопросу о транспортных средствах трипольской культуры // РА. № 1. С. 15-28.

Maran J. 2004. Kulturkontakte und Wege der Ausbreitung der Wagentechnologieim 4. Jahrtausend v. Chr. In: Fansa M., Burmeister S. (Hrsg.). Rad und Wagen. Der Ursprungeiner Innovation. WagenimVorderen Orient und Europa. Mainz-am-Rhein. S. 429-442.

\section{GROUND VEHICLES OF THE TRIPOLYE CULTURE AND INNOVATION OF WAGON}

\section{Nataliya Chub \\ German Archaeological Institute's Roman-Germanic Commission, Frankfurt, Germany}

Keywords: Tripolye culture; wagon innovation; models of sledges, wheels and wagons; absolute chronology; statistical analysis.

Most researchers of Tripolye culture agree that the models of sledges known from settlements of this culture are stylized representations of their real prototypes. At the same time, there is still no consensus as to whether the bearers of the Tripolye culture used wheels and carts. Wagon models that would have corresponded to real vehicles are unknown in the Tripolye culture.

Wheel models are a numerous category of finds; but, in most cases, there are doubts as to whether these objects were really models of vehicle wheels rather than, perhaps, spinning whorls. However, in some settlements, zoomorphic, sometimes jar-like, figures with horizontal holes in the legs were found. The combination of these figures with wheel models can be interpreted as a representation of a wagon. This report considers the arguments in favor of a fairly early invention of wheel and cart in the territory of the distribution of the Tripolye culture.

\section{ОСОБЕННОСТИ КУРГАННОГО ЛАНДШАФТА МЕЖДУ ДНЕСТРОМ, ПРУТОМ И ДУНАЕМ}

\author{
Д. А. Топал \\ Университет Высшей антропологической школь, Кишинёв, Молдова
}

DOI: 10.31600/978-5-907053-35-9-29-32

Ключевые слова: Северо-Западное Причерноморье, культурный ландиабт, курганы, погребальный обряд, монументальность.

Традиция погребения под насыпью - так называемые могильные холмы или курганы распространена на всех заселенных континентах планеты, кроме, наверное, Австралии. В Евразии курган - наиболее частый вид археологического памятника от Испании до Японии. На территории Европы выделяется несколько курганных зон: атлантическая, нордическая, центральная, средиземноморская и восточноевропейская (Darvill 2013: 144-146). В пределах восточноевропейской зоны выделяется территория Северо-Западного Причерноморья, ограниченная черноморским побережьем и Дунаем с юга, Днестром - с востока и Прутом - с запада.

Культурный ландшафт Северо-Западного Причерноморья с доисторической эпохи оказался под влиянием трех основных факторов: юго-восточноевропейского (балканского), восточноевропейского (степного) и центральноевропейского (лесостепного). Это во многом определило статус региона как контактной зоны (Dergachev et al. 1991: 1) - территории, где «культуры встречаются, сталкиваются и взаимодействуют друг с другом, часто в условиях крайне асимметричных отношений (Pratt 1991: 34).

Практика возведения насыпей в Северо-Западном Причерноморье появляется не позже второй четверти IV тыс. до н. э. (Manzura 2009: 20), а возможно, даже в V тыс. до н. э. 


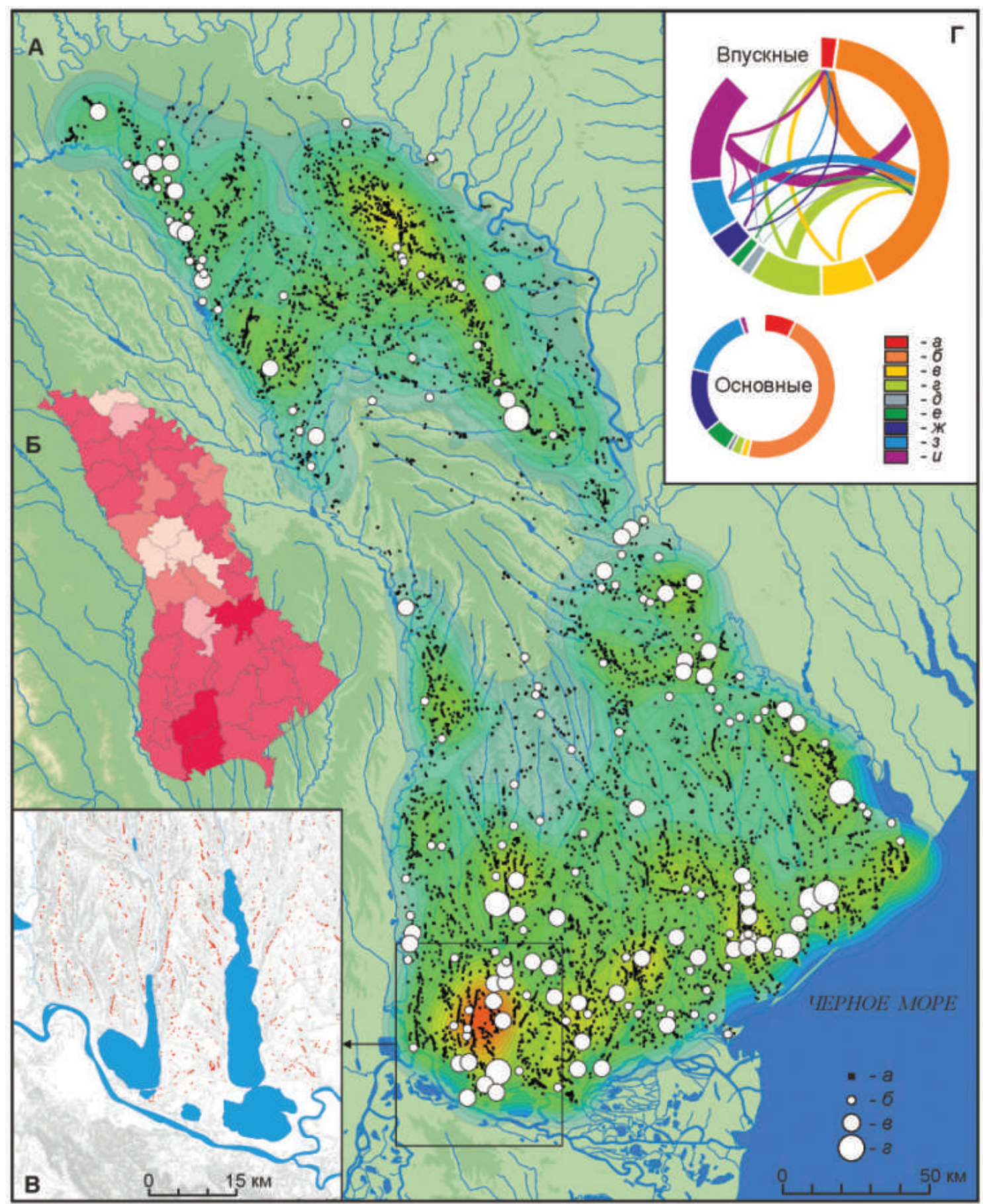

Рис. 1. Курганы между Днестром, Прутом и Дунаем: А - соотношение исследованных и неисследованных курганов ( $a$ - нераскопанные курганы; 6-г - раскопанные курганы: 6- насыпи диаметром 1-3 м; в - насыпи диаметром 4-15 м; г - насыпи диаметром более 15 м); Б - плотность курганов по районам Правобережной Молдовы и западной части Одесской области Украины; В — курганы левобережной части Нижнего Подунавья; Г — культурнохронологические определения исследованных курганных погребений ( $a-$ энеолит, усатовская; 6 - ямная; в - катакомбная; 2 - культура многоваликовой керамики (бабинская); д - сабатиновская; $e$ - белозерская; ж - скафская; 3 - сарматская; $u$ - средневековье) 
(Govedarica 2011: 34). Позже курган становится важнейшей частью погребального обряда различных культур эпохи бронзы, железного века, римского времени, средневековья и даже нового времени, вплоть до рубежа XVIII-XIX вв.

Всего между Днестром и Прутом было раскопано и опубликовано более 700 курганов (и более 5000 курганных погребений). Первые раскопки курганов проведены Ф. И. Кнауэром в 1888 г., а пик исследований курганных памятников приходится на середину 1980-х гг. Предварительная статистика (рис. $1, D$ ) указывает на наличие двух основных периодов сооружения курганов - ранний бронзовый век (ямная и катакомбная культуры, 51 \%) и скифо-сарматское время (28\%).

Анализ топографических карт, созданных до масштабных археологических исследований (трехверстовая карта Ф.Ф.Шуберта 1883 г.) и спутниковых данных (WorldImagery, GoogleMaps) в сочетании с цифровыми моделями рельефа (DEM) AsterDEM, SRTM) позволил выявить основные районы скоплений курганных насыпей (по предварительной оценке, их более 10000 ) и линейный характер их распределения (рис. 1, A, B). Выяснилось, что курганные цепочки (длиной до 20-30 км) тесно связаны с особенностями рельефа - расположены на водоразделах и вытянуты параллельно к рекам и другим источникам воды (рис. $1, C$ ).

Линейный характер паттернов, по которым сооружались насыпи, не исключает их вероятной связи с древними дорогами, маркировкой маршрутов миграций (Løvschal 2013). Кроме того, курган может рассматриваться в качестве социокультурного маркера, указывающего на присутствие культурных сообществ и их границ. С другой стороны, исследование планировки курганных некрополей в качестве неких «городов мертвых» может позволить выявить «урбанистические» паттерны сообществ, которые не создавали долговременных поселений. Поэтому в цели и задачи данного исследования входит раскрытие принципов организации курганного ландшафта, конструктивных паттернов и механизмов последующего использования курганных насыпей представителями иных культурных сообществ. Другими словами, как доисторические и протоисторические сообщества видоизменяли естественный ландшафт согласно своим идеологическим представлениям и как эволюционировала сама идея курганного захоронения на протяжении тысячелетней истории данной погребальной практики.

\section{Литература}

Darvill T. 2013. Monuments and Monumentality in Bronze Age Europe. In: Fokkens H., Harding A. (eds.). The Oxford Handbook of the European Bronze Age. Oxford. P. 140-158.

Dergachev V., Sheratt A., Larina O. 1991. Recent results of Neolithic research in Moldavia (USSR). In: Oxford Journal of Archaeology 10 (1). P. 1-16.

Govedarica B. 2011. Die sakrale Symbolik des Kreises: Gedanken zum verborgenen Sinnbild der Hügelbestattungen. In: Ancestral landscapes. Burial mounds in the Copper and Bronze Ages (Central and Eastern Europe-Balkans-Adriatic-Aegean, $4^{\text {th }}-2^{\text {nd }}$ millennium B.C.). Proceedings of the International Conference held in Udine, May $15^{\text {th }}-18^{\text {th }} 2008$. Lyon. P. 33-46.

Løvschal M. 2013. Ways of Wandering in the Late Bronze Age Barrow Landscape of the Himmerland-area, Denmark. In: D. Fontijn et al. (ed.) Beyond Barrows. Current research on the structuration and perception of the Prehistoric Landscape through Monuments. Leiden. P. 225-250.

Manzura I. 2009. Entstehung der ersten Grabhügel in nordpontischen Steppen im Kontext der nordwesteuropäischen Parallelen. In: Sava E. et al. (Hrsg.). Der Schwarzmeerraum vom Äneolithikum bis in die Früheisenzeit (5000-500 v. Chr.): Globale Entwicklung versus Lokalgeschehen. Internationale Fachtagung von Humboldtianern für Humboldtianer. Humboldt-Kolleg in Chişinău, Republica Moldova (4.-8. Oktober 2009). Programm. Chişinău. S. 20-22.

Pratt M. L. 1991. Arts of the Contact Zone. In: Profession. P. 33-40. 


\title{
PATTERNS OF KURGAN LANDSCAPE \\ BETWEEN DNIESTER, PRUT AND DANUBE RIVERS
}

\author{
Denis A. Topal \\ University of High Anthropological School, Chişinău, Republic of Moldova
}

Keywords: kurgans, cultural landscape, burial rite, North-Western Black Sea region, monumental features.

The practice of construction of barrows over the buried dead appeared in the Pontic area of Eastern Europe in the Late Eneolithic (3900-3800 BC). Since that time the barrow rite had become an important part of the funeral practices among various cultures of the Bronze and Iron Ages, and Roman, Medieval and Modern periods until the turn between the $18^{\text {th }}-19^{\text {th }}$ centuries. The preliminary statistics of the excavated barrows demonstrates the existence of two main periods in the building of tumuli: the Early Bronze Age (Usatovo, Yamnaya and Catacomb cultures) and the Scythian-Sarmatian period. Over 700 kurgans (more than 5000 burials) have been excavated and published in the area between the Dniester and Prut rivers. The first barrows in this region were excavated in the late $19^{\text {th }}$ century, but the peak of investigations of kurgans is documented in the 1970-1980s. Analysis of satellite photos and topographical maps composed before the spread of the excavations identified the main concentrations of barrows (over 10,000) and the linear patterns of their distribution related with the features of the natural relief. The lines of the mounds are predominantly arranged along the ridges and are oriented parallel to the riverbeds. Preliminary analysis of the lines of excavated barrows suggests that the burial grounds were from the beginning preplanned by people of the early cultures and subsequently used according to the linear pattern. The latter probably was related to the roads, trackways and migration routes.

\section{БЫТЬ МАЙКОПСКИМИ ГОНЧАРАМИ: РЕЗУЛЬТАТЫ ТЕХНОЛОГИЧЕСКОГО АНАЛИЗА}

\author{
М. Исерлис \\ Германский археологический институт, Берлин, Германия
}

DOI: 10.31600/978-5-907053-35-9-32-34

Ключевые слова: «майкопский феномен», Лейлатепе, Уст-Джегута, Серёгинское, курган Ошад, технология производства керамики.

«Майкопский феномен» привлекал и привлекает внимание множества исследователей самых разных научных дисциплин, а также вызывает споры вне стен академических заведений. Его появление зачастую связывают с влияниями и/или связями вне Северного Кавказа (Кореневский 2008; Sagona 2018: 143-203; включая различные мнения и упомянутую литературу). Различные морфологические и технические признаки майкопской керамики служили основой для гипотез о связях северокавказских общин с Южным Кавказом, Передней Азией и Европой. Но по сей день наше представление о технологии самого распространенного и базисного аспекта материальной культуры «майкопского феномена» керамики - очень фрагментарно и не позволяет вести дискуссию, для которой нужны упорядоченное описание технологии и основанный на нем сравнительный анализ. Стартовавший летом 2017 г. проект ставит своей целью создать базисное сравнительное описание технологии майкопской и лейлатепинской керамики из избранных памятников и организации керамического производства в социо-культурном контексте.

В докладе представлены результаты анализов четырех коллекций, происходящих из поселений Усть-Джегута, Серёгинское и Лейлатепе, а также из кургана Ошад и устьджегутинских курганов. Проект основан на просмотре автором коллекций керамических изделий из 16 памятников, находящихся в разных географических регионах и ландшафтах 